\title{
PERSEPSI MAHASISWA TERHADAP SENI RUPA TRADISI DAN KONTEMPORER SERTA RELASI PROSES PENJELAJAHAN IDE KREATIF DALAM BERKARYA
}

\author{
Narsen Afatara', Sigit Purnomo Adi , Sayid Mataram ${ }^{3}$ \\ Fakultas Seni Rupa dan Desain, Universitas Sebelas Maret Surakarta \\ narsen_afatara@yahoo.com', sigitpurnomoadi61@gmail.com², zooncoen@yahoo.com³
}

Nadia Sigi Prameswari

Fakultas Bahasa dan Seni, Universitas Negeri Semarang

nadiasigi87@gmail.com

\begin{abstract}
The essence of art is creating beauty. Since ancient times beauty is something that is always sought after by humans. The beauty is getting worse due to traditional art increasingly abandoned. Traditional art is all things related to values in a particular community which are maintained purely from generation to generation. In contrast to contemporary art, one of the most prominent and prominent characteristics in contemporary art is the disappearance of boundaries between art. Both forms and styles of fine arts need to be preserved by students as the next generation. The importance of preserving art is part of the preservation of the arts and culture of the nation's heritage. Traditional and contemporary art are taught in the realm of education, especially at the university level through fine arts courses. The purpose of this study is to find out the perceptions of art students on traditional art and contemporary art, so that students as young people can identify and determine their interest in one form and style between traditional and contemporary art.
\end{abstract}

\section{Keyword: Fine Art, Contemporary and Traditional}

\begin{abstract}
ABSTRAK
Hakikat seni adalah menciptakan keindahan. Sejak zaman dahulu keindahan adalah sesuatu yang selalu dicari oleh manusia. Keindahan tersebut semakin terpuruk akibat seni rupa tradisional semakin ditinggalkan. Seni rupa tradisional adalah semua hal yang berkaitan dengan nilai-nilai di dalam suatu komunitas masyarakat tertentu yang dijaga kemurnian dan keutuhannya secara turun-temurun. Berbeda dengan seni rupa kontemporer, salah satu karakteristik yang ada dan paling menonjol dalam seni kontemporer adalah menghilangnya batas-batas antarmedia seni. Kedua bentuk dan gaya seni rupa perlu dilestarikan oleh mahasiswa sebagai generasi penerus. Pentingnya melestarikan seni rupa merupakan bagian dari pelestarian kesenian dan kebudayaan warisan bangsa. Seni rupa tradisional dan kontemporer diajarkan di ranah pendidikan, khususnya di tingkat perguruan tinggi melalui mata kuliah seni rupa. Tujuan dari kajian ini adalah untuk mengetahui persepsi mahasiswa seni rupa terhadap seni rupa tradisional dan seni rupa kontemporer, sehingga mahasiswa sebagai generasi muda dapat mengidentifikasi dan menentukan minatnya terhadap salah satu bentuk dan gaya antara seni rupa tradisional dan kontemporer.
\end{abstract}

\section{Kata kunci: Seni Rupa, Kontemporer dan Tradisional}




\section{PENDAHULUAN}

Indonesia merupakan negara kesatuan yang terdiri dari berbagai suku bangsa dan budaya. Keanekaragaman etnisitas menjadikan Indonesia kaya akan segala warisan budaya. Kondisi Indonesia sebagai negara kepulauan dengan berbagai suku bangsa yang memiliki keragaman pola pikir, seni, agama, pengetahuan, bahasa serta tradisi budaya lokal dengan karakteristik yang unik dan berbeda (Widiastuti, 2013: 8). Bangsa Indonesia memiliki keanekaragaman budaya yang biasa disebut dengan masyarakat multikultural (Ridwan, 2015: 254).

Kesenian merupakan warisan budaya bangsa. Warisan budaya biasanya dapat berupa karya seni, arsip, dokumen, dan foto, karya tulis cetak, audio visual berupa kaset, video, dan film (Galla, 2001: 10). Kesenian disini dapat dilihat sebagai identitas kultural atau budaya masyarakat Indonesia yang berfungsi secara sosial dan ritual dalam artian kesenian tidak sekadar sebagai hiburan yang menciptakan kegembiraan, namun dapat menjadi pola budaya sekaligus menjadi media yang mampu memfasilitasi doa dan harapan (Irianto, 2017: 90). Salah satu kesenian yang populer adalah seni rupa.
Seni sebagai bagian yang tidak terpisahkan dari kehidupan manusia memang selalu berkembang di berbagai aspek-aspek di dalam seni itu yang merupakan upaya sadar untuk mewariskan nilai-nilai dari generasi ke generasi (Anam, et.al, 2016: 3). Seni menciptakan keindahan. Tidak dapat dipungkiri lagi bahwa seni selalu hadir dalam keindahan. Sejak zaman dahulu keindahan adalah sesuatu yang selalu dicari oleh manusia (Felix, 2012: 617). Keindahan tersebut semakin terpuruk akibat seni rupa semakin ditinggalkan, utamanya seni rupa tradisional. Seni rupa tradisional dianggap tidak dapat mengikuti perkembangan zaman sehingga hanya sedikit generasi muda yang menyukai seni rupa tradisional.

Seni rupa penting untuk dilestarikan karena seni rupa merupakan bagian dari kesenian yang tumbuh dan berkembang dalam sebuah peradaban. Pada dasarnya manusia itu membutuhkan pemuasan perasaan akan hal-hal yang indah atau memiliki estetika, di samping kebutuhan material lainnya. Keindahan ini terekspresikan melalui seni pertunjukan, seni rupa, seni media rekam. Rumpun seni pertunjukan terdiri dari seni musik, tari, dan teater (Wiratmoko, 2017). Pentingnya melestarikan seni rupa merupakan bagian da- 
ri pelestarian kesenian dan kebudayaan warisan bangsa. Eksistensi budaya bangsa dapat ditunjukkan melalui identitas bangsa berupa bentuk seni dan budaya masyarakatnya yang terus dilestarikan (Gustianingrum \& Affandi, 2016).

Seni rupa tradisional maupun seni rupa kontemporer merupakan dua bentuk dan gaya dari seni rupa yang perlu di terapkan melalui pendidikan sebagai wujud pelestarian warisan budaya bangsa. Selain mejadi medium pelestarian seni dan budaya bangsa, pembelajaran seni rupa juga dapat mendorong pengembangan emosional dan imajinasi anak (Elman \& Watts, 2014). Di sisi lain, dalam dimensi pedagogis, pembelajaran seni rupa di ranah universitas cenderung bersifat multilingual, multidimesional dan multikultural (Sa -chari, 2006). Multilingual bermakna, seni diekspresikan lewat berbagai media relevan secara kreatif (Zulkifli, 2012).

Seiring perkembangan zaman, minat masyarakat global mulai beralih pada estetika grafis dan tidak lagi mengindahkan seni rupa sebagai representasi warisan budaya bangsa (Risdaryanthi, 2014: 88). Perkembangan yang terjadi dari seni rupa tradisional menjadi seni rupa kontem porer merepresentasikan perubah- an paradigma yang mempengaruhi persepsi mahasiswa. Hal ini menarik untuk dikaji bagaimana peranan kedua gaya seni rupa dapat menarik minat genersi muda khususnya mahasiswa dalam melestarikan kesenian sebagai warisan budaya bangsa. Keunikan dan karakteristik gaya dari seni rupa memberikan intepretasi dan persepsi yang menarik untuk dikaji sehingga dapat diketahui salah satu seni rupa yang diminati oleh mahasiswa dan dapat dikembangkan karya-karya baru sebagai bentuk pelestarian seni dan budaya bangsa.

\section{Metodologi Penelitian}

Penelitian ini menggunakan pe -nelitian kualitatif deskriptif. Berisi data yang dikumpulkan berwujud kata-kata dalam kalimat atau gambar yang mempunyai arti lebih dari sekedar angka atau jumlah. Riset kualitatif tidak memotong halaman-halaman cerita dan data lain dengan simbol angka. Riset kualitatif mendasarkan pada realitas internal yang berkiblat pada fenomenologi, dengan menganggap ke-benaran sebagai suatu hasil persetujuan sesuai dengan kondisi sosial. Peneliti mencoba menganalisis data dengan semua kekayaan data yang penuh nuansa sedekat mungkin dengan bentuk asli 
-nya, seperti pada saat dicatat (Sutopo,1996). Menurut Nasution (2003) penelitian kualitatif disebut juga pene -litian naturalistik, karena dalam penelitian kualitatif dilakukan dalam set -ting latar yang alamiah atau natural.

Data atau informasi yang didapatkan dari penelitian ini sebagian besar data kualitatif. Pengumpulan data dilakukan pada natural setting (kondisi yang alamiah), sumber data primer dan teknik pengumpulan data lebih banyak diperoleh melalui observasi, wawancara mendalam, dan dokumentasi. Berbagai data atau informasi tersebut didapatkan melalui informan. Subyek dalam penelitian ini adalah mahasiswa UNS, lebih khusus lagi mahasiswa Fakultas Seni Rupa dan Desain (FSRD) jurusan Seni Rupa Murni. Subyek yang dipilih adalah beberapa mahasiswa yang telah mempelajari mata kuliah seni rupa yang terdiri dari seni rupa tradisional dan seni rupa kontemporer.

\section{PEMBAHASAN}

\section{Konsep Seni Rupa Tradisional}

Seni rupa tradisional ditilik dari istilahnya pasti berkaitan dengan kar -ya seni yang keberadaannya selalu dilestarikan atau diwariskan secara kontinyu oleh regenerasinya tanpa ada perubahan baik dalam hal ba- han, teknik maupun nilai-nilai estetik simbolik filosofisnya, tetapi apabila terjadi perubahan kemungkinan tidak begitu besar dan mengganggu eksis -tensi kebermaknaan nilai tradisinya (Iswahyudi, 2010: 2). Seni rupa tradisional adalah semua hal yang berkaitan dengan nilai-nilai di dalam suatu komunitas masyarakat tertentu yang dijaga kemurnian dan keutuhannya secara turun-temurun. Jenis kesenian ini diantaranya ukiran Toraja, patung suku Asmat, batik tulis keraton dan lain sebagainya. Seni rupa tradisional di era ekonomi global, berada diantara benturan antara nilai tradisional yang mengabdi pada harmoni, keselarasan, dan mistis dengan nilai-nilai kontemporer yang cenderung terorganisasi oleh perkembangan teknologi informasi, konsumsi budaya, dan permainan media massa (Irianto, 2016).

Kesenian tradisi dan seni rupa tradisional di dalamnya, menjadi eks -presi masyarakat pendukung untuk menciptakan keserasian dan keselarasan antara manusia dan lingkungannya, yang kemudian perlunya penyesuaian diri dengan kebutuhan pasar, sejalan dengan tuntutan global (Coates, 2017). Seni tradisional kian menghilang dikarenakan modernisasi, industrialisasi ataupun pengaruh luar. Eksistensi seni rupa 
tradisional mengalami marjinalisasi karena dianggap kurang memenuhi tuntutan standar industri pariwisata yang merupakan buah dari ekonomi dan kehidupan di era globalisasi (Irianto, 2017). Hal tersebut dianggap sebagai fenomena bagi kalangan tertentu. Seni rupa tradisional sudah ada sejak turun-temurun dan sudah menjadi tradisi di masyarakat. Ciri khas suatu suku atau bangsa bisa dilihat dari seni rupa tradisionalnya. Kesenian tradisional, bagi masyarakat pendukung dipandang sebagai salah satu media yang mam pu melegitimasi keberadaan serta mempertahankan identitas mereka (Radzuan, et.al., 2014).

\section{Konsep Seni Rupa Kontemporer}

Seni rupa kontemporer lahir sebagai penentang asas dari ide-ide seni rupa era modern. Seni rupa kontemporer muncul setelah banyak melalui konferensi kesenian dan seminar internasional sebagai suatu bentuk atau gaya baru di tataran seni rupa yang menggaet aspek plural, multikultural, etnik dan lain sebagainya. Dari situlah muncul istilah se -ni rupa 'kontemporer atau 'contemporary art yang lebih dikenal dengan seni rupa post-modern (Yustiono, 19 95). Perkembangan seni rupa kontemporer dipengaruhi cara berfikir perupa dalam menciptakan konsep yang terpengaruh pandangan global. Pengkajian dibidang seni rupa penting digalakan sehingga wacana seni rupa kontemporer agar dapat gointernasional. Perpaduan antara pen -ciptaan dan pengkajian yang padu akan berdampak pada perkembangan seni rupa kontemporer yang kuat, berakar lokal, berwawasan global (Karja, 2007: 34).

Perkembangan seni rupa saat ini yang lebih dikenal sebagai seni rupa kontemporer, menurut Becker lebih berfokus terhadap penemuan organisasi-organisasi baru atau metode-metode baru dalam mendistribusikan karya seni. Hal ini dikarenakan beberapa sistem yang ada mungkin kurang sesuai untuk karyakarya seni baru, atau karya-karya seni tertentu tidak cocok untuk sistem tertentu, dan sebagainya (Becker, 1982: 129). Salah satu karakteristik yang ada dan paling menonjol dalam seni kontemporer adalah menghilangnya batas-batas antarmedia seni. Batas antara seni lukis dan seni patung, antara patung dan kriya, atau seni yang lain, menjadi semakin cair. Kotak-kotak yang memisahkan media seni yang satu dengan yang lain tidak ada lagi, sehingga dengan sendirinya berbagai kriteria dan konvensi yang se- 
belumnya ada menjadi tidak berlaku lagi (Anusapati, 2015).

Seni Rupa Tradisional dan kontemporer merupakan dua gaya seni rupa yang masih berkembang hingga saat ini. Pada perkembangannya di Indonesia, seni rupa tradisional atau seni rupa klasik merupakan seni yang berkembang sejak Nusantara bercorak Hindu-Buddha yang kemudian berkembang hingga masa keislaman di Nusantara (Yudoseputro, 1990). Seni rupa tradisional merupakan penggambaran dalam simbol-simbol yang terlambang dari budaya dan materials manusia dari masa lampau yang dituangkan ke dalam bentuk visual (Irianto, 2011). Seni rupa tradisional memberikan kearifan pada kehidupan dengan dapat berperan sebagai media yang dapat mengkomunikasikan bentuk pendidikan maupun kritikan secara luas dengan bahasa yang lebih halus (Purwanto, 2006). Meskipun begitu, banyak dari generasi muda yang kesulitan menafsirkan dan mendefinisikan makna dari suatu karya seni rupa tradisional sehingga pesannya tidak dapat diterima (Rudy, 2013).

Seni kontemporer atau seni modern menjadi lebih diminati karena memiliki unsur-unsur otonomi, kebebasan, dan progresivitas yang menjadi elemen penting dalam sebuah karya seni rupa kontemporer (Nugroho \& Himawan, 2014). Seni rupa kontemporer yang otonomi berarti menyesuaikan konteksnya dengan perkembangan zaman, memiliki unsur kebebasan berarti penggambaran dari keleluasaan makna dan sifat dari unsur karya seni, dan seni rupa progresivitas yang berarti meng -alami kemajuan dan peningkatan terhadap kualitas karya seni.

Seni rupa kontemporer lebih mengutamakan makna atau pesan yang ter-kandung di balik bentuk visual di-bandingkan aspek estetikanya yang formalistik (Hardy, 2006). Berbeda dengan sebaliknya, seni rupa tradisional lebih mengutamakan estetika formalistik dan pesan yang terkandung sulit dimaknai secara universal. Mendelsohn dan Moritz mengungkapkan tujuan dari seni bukanlah keindahan melainkan kebaikan.

Sulzer menyebutkan yang dapat dikatakan indah adalah yang me-ngandung kebaikan (Kadir, 1974). Sehingga seni yang lebih baik adalah seni rupa yang indah yang memberikan pesan kebaikan dan hal tersebut secara signifikan tergambar pada prinsip seni rupa kontemporer. 
Seni rupa menjadi adiksi bagi sebagian orang di dunia, baik dari gambar-gambar kartun kesukaan, lukisan-lukisan alam hingga rupa patung yang menunjukkan bentuk yang indah dan menarik di pandang, tak terkecuali bagi mahasiswa. Persepsi mahasiswa dalam mengamati dan mempelajari seni rupa murni dapat menjadi penggambaran minat dan motivasi generasi muda dalam melestarikan budaya bangsa. Dalam konteks ini, mahasiswa menganalisis sejauh mana dua gaya seni rupa yang baik dan menarik sehingga dapat membangun motivasi generasi muda, terutama di level mahasiswa Seni Rupa Murni dalam menciptakan karya seni rupa yang menarik dan diterima banyak khalayak. Wawancara dilakukan oleh peneliti terhadap beberapa responden yang akan menjelaskan mengenai pengalaman mengenal Seni Rupa sebelum berkuliah, persepsi dalam mempelajari seni rupa dan menciptakan produk atau karya seni rupa.

\section{Pengalaman Mahasiswa tentang Seni Rupa Pra-Kuliah}

Seni rupa telah banyak berkembang dari masa ke masa, begitu juga dengan pengalaman seseorang dalam merasakan, menikmati bahkan mempelajari keindahan dari seni rupa. Seorang mahasiswa seni rupa khususnya, tentu memiliki pengalaman tersendiri sehingga mempengaruhi motivasi agar dapat berkuliah di jurusan Seni Rupa. Kekayaan karya seni rupa dengan estetikanya dapat menarik seseorang untuk mengenal seni rupa. Secara umum, pengalaman yang didapatkan oleh mahasiswa sebelum mengenal lebih jauh disiplin ilmu seni rupa di dapat melalui kegemaran melihat estetika gambar kartun kartun dan animasi yang mengadiksi, seperti halnya kartun yang populer adalah Naruto, Doraemon, Spongebob Squarepants, dan lain sebagainya. Hal ini sesuai dengan yang di argumentasikan oleh Imam Bukhori :

"Dari kecil saya suka gambar, dulu masih terpengaruh sama kartun-kartun, kayak misal Naruto, kayak anime-anime gitu.... awalnya suka seni rupa dari situ, saya melihat anime, saya pikir itu bagus kemudian saya coba untuk meniru, menggambarnya" (Wawancara dengan Imam Buhkori pada tanggal 1 Agustus 2018)

Imam Bukhori adalah mahasiswa Fakultas Seni Rupa dan Desain, Jurusan Seni Rupa Murni semester 8. Pada wawancara tersebut, Imam melanjutkan ceriteranya bahwa pengalamannya dalam mengenal istilah seni rupa dialaminya saat masih di level Sekolah Dasar, 
kemudian pengalamannya tersebut membuat Imam menggemari seni rupa sehingga saat di Sekolah Menengah Pertama (SMP), Imam mengikuti ekstrakulikuler menggambar. Hal serupa dikemukakan oleh Sherly Debora bahwa pengalaman mengenal istilah seni rupa yang sudah didapatkan sejak di level Sekolah Dasar. Hanya saja pengalaman yang didapat Sherly dalam mengenal istilah seni rupa ini tidak sesuai dengan yang di alami Imam Bukhori yang mengenal istilah seni rupa melalui kegemaran Imam terhadap kartun-kartun Anime.

"Pastinya udah pernah ya, kita kan udah diajarkan dari SD sampai SMK, tapi hanya mendasar" (Wawancara dengan Sherly Debora pada tanggal 2 Agustus 2018).

Pada wawancara yang dilakukan dengan mahasiswa jurusan Seni Rupa murni lainnya, mengemukakan bahwa pengalaman dalam mengenal istilah seni rupa sudah sejak lama di ajarkan melalui mata pelajaran wajib di sekolah, sehingga secara umum seharusnya semua orang sudah dapat mengenal istilah seni rupa melalui pendidikan formal di Sekolah. Hal tersebut sesuai dengan yang dijelaskan oleh Ari Wibowo melalui wawancara yang dilakukan dengan peneliti :
"Kalau itu sih sudah menjadi mata pelajaran wajib biasanya, dari sekolahan itu sendiri sudah lebih ke dasar-dasar seni rupa, kayak 2 dimensi seperti contoh-contohnya" (Wawancara dengan Ari Wibowo pada tanggal 2 Agustus 2018).

Ari Wibowo merupakan mahasiswa Fakultas Seni Rupa dan Desain Jurusan Seni Rupa Murni semester 2. Wawancara yang dilakukan oleh peneliti banyak menemui pernyataan yang menarik terkait pengalaman yang diungkapkan melalui ceritera pribadi responden. Pengalaman-pengalaman pra-kuliah mahasiswa Seni Rupa dalam mengenal istilah seni rupa di jenjang pendidikan formal dialami juga oleh Khairul Imam. Khairul Imam merupakan mahasisiwa Fakultas Seni Rupa dan Desain, Jurusan Seni Rupa Mur -ni semester 6. Khairul menuturkan :

\begin{abstract}
"Kalau dulu dari SD, SMP, itu saya suka tapi gak terlalu bisa, skill saya terbatas, Cuma ketika SMK saya masuk ke jurusan seni, di Kriya Loka, dari situ saya mulai mengenal lebih jauh. Kalu SD atau SMP itu pengalaman visualnya masih sedikit, tapi kalau di SMK kita bisa main ke kelaskelas lain melihat karya-karya, Iha mulai cukup seneng pas SMK". (Wawancara dengan Khairul Imam pada tanggal 9 Agustus 2018).
\end{abstract}

Dalam penuturan selanjutnya, pada masa SMK Khairul Imam mulai menyukai Fine Art atau Seni Rupa 
Murni meskipun la berada pada jurusan Seni Kriya Loka. Pengalaman tersebut dialaminya karena sering melihat ke kelas lain di jurusan lain dan mulai mengagumi seni rupa murni. Pengalaman dalam mengenal istilah seni rupa sebenarnya sudah Khairul dapatkan sejak di Sekolah Dasar dan SMP hanya saja sebatas mengetahui sedikit dan tidak mendalam. Pendapat lain dikemukakan oleh Dewi wulansari dengan persepsi yang berbeda dari responden lain mengenai pengelaman mengenal istilah lain dari seni rupa :

"Dulu setahu aku seni rupa itu, seni tapi di bidang rupa, rupa itu berarti gambar jadinya yang visual -lah" (Wawancara dengan Dewi wulansari pada tanggal 2 Agustus 2018).

Secara umum pada wawancara yang dilakukan oleh peneliti, banyak yang menceritakan pengalamannya dalam mengenal istilah seni rupa. Akan tetapi selain itu, ada pula yang mengemukakan pendapat lain dalam mengenal istilah seni rupa, seperti halnya mahasiswa yang mendefinisikan seni rupa sebagai seni yang memiliki rupa atau bentuk visual. Dari sekian banyak hasil wawancara yang dilakukan oleh peneliti, banyak diantaranya sudah mengenal seni rupa dari berbagai aspek kehidupan, salah satunya mela- lui pendidikan formal, namun masih sedikit atau tidak semua responden pra-kuliah seni rupa yang sudah mendapatkan pengalaman secara langsung melihat karya-karya seni rupa dalam bentuk pameran. Salah satu responden yang dilakukan wawancara mengungkapkan bahwa :

"kalau pameran itu saya belum pernah, baru kuliah ini baru menjelajahi ke pameran-pameran gitu". (Wawancara dengan Sherly Debora paada tanggal 2 Agustus 2019)

Sherly Debora merupakan mahasiswi Fakultas Seni Rupa dan Desain, Jurusan Seni Rupa Murni semester 4 . Sherly berpendapat bah -wa pengalaman pertamanya menge -nal seni rupa adalah melalui pameran-pameran karya seni rupa. Selebihnya, responden menyadari bahwa banyak hal yang di lihat di sekelilingnya adalah bentuk dari karyakarya seni rupa, seperti halnya dari mengamati kartun atau karya-karya batik di pasar. Seperti halnya dengan pendapat yang disampaikan oleh Ari Wibowo yang menjelaskan bahwa :

\footnotetext{
"awalnya nonton kartun, setelah itu kan di pasar lihat batik. Itu kan sudah termasuk karya seni" (Wawancara dengan Ari Wibowo Pada tanggal 2 Agustus 2018).

Hal senada juga diutarakan oleh Imam Bukhori yang berpen-
} 
dapat bahwa dirinya pernah melihatlihat hasil karya seni rupa sebelum berkuliah di jurusan Seni Rupa murni meskipun melihatnya melalui media atau dalam kata lain, tidak melihatnya secara langsung. Imam menuturkan bahwa :

"Melihat karya seni ya Cuma dari katalog, buku-buku gitu karena masih SD juga kalau melihat secara langsung saya belum pernah, saya baru melihat secara langsung ketika ke rumah sau dara atau kemuseum tapi jarang" (Wawancara dengan Imam Bukhori pada tanggal 1 Agustus 2018)

Pengalaman melihat karya seni memang bisa melalui media perantara sekalipun seperti melalui katalog bergambar. Dari pengalaman melihat-lihat karya seni rupa yang ada kemudian melahirkan perasaan tertentu yang dalam dan emosional. Seseorang dapat merasakan kesedihan saat melihat suatu lukisan tertentu, seseorang juga dapat merasakan kebahagiaan setelah melihat rupa dari seni yang diciptakan perupa, ataupun perasaan kebebasan yang melekat dalam karya-karya seni rupa. Tentunya sebelum menge -nal lebih jauh mengenai ilmu seni rupa di perkuliahan, responden mahasiswa seni rupa murni memiliki pengalam tersendiri dalam menyikapi dan menuangkan perasaannya ketika melihat suatu karya seni. "kayanya seni itu bebas bisa mengekspresikan diri, sesuai perasaan, jadi kaya udah tertarik sik sama seni itu" (Wawancara dengan Ari Wibowo pada tanggal 2 Agustus 2018)

Pada wawancara yang dilakukan oleh peneliti, Ari menjelaskan bahwa ketertarikannya dengan seni rupa tumbuh karena karya-karya yang Ari temui telah memberikan penggambaran tentang kebebasan berekspresi sehingga seni rupa men -jadi sesuai dengan perasaan yang kemudian memunculkan ketertarikan bagi Ari. Karya seni rupa menjadi wakil bagi perasaan penikmatnya, saat memberikan pengalaman baru, pengalaman yang membahagiakan, emosi tentang kesedihan, dan perasaan lainnya yang timbul. Hal tersebut dapat menjadi gejolak bagi yang dapat merasakan pengalaman yang terbagi antara karya seni rupa kepada penikmatnya, seperti yang dituturkan oleh Imam Bukhori :

"Kalau saya bilang estetik, ada pengalaman baru, pengalaman yang indah juga pengalaman sedih dan itu sangat mempengaruhi perasaan saya tergantung lukisan yang dilihat.misal dulu saya sering liat lukisan pemandangan yang umum dilihat ya saya melihat itu sebagai suatu keindahan lebih ke indahan alam, dulu saya juga suka bermain di sawah kebetulan lukisan yang saya lihat adalalah lukisan sawah jadi saya mengalami suatu gejolak psikologis, oh itu indah, membangkitkan suasana ketika saya 
nermain di sawah dulu" (Wawancara dengan Imam Bukhori Pada tanggal 1 Agustus 2018)

Seni rupa menjadi representasi penggambaran situasi dan perasaan bagi perupa yang menjadi medium penyampai pesan. Hal tersebut tertuang dalam bentuk karya yang dapat dinikmati dan di terima orang banyak, sehingga dapat dikatakan bahwa seni rupa dapat menjadi media komunikasi antara perupa dengan banyak orang yang dapat merasakannya dan menerima estetika yang ditawarkannya.

\section{Mempelajari Mata Kuliah Seni Rupa}

Secara konseptual, seni rupa memiliki banyak definisi yang memberikan pengertian tertentu secara perspektif sehingga seseorang dapat memahami dan mengaplikasikannya dalam kehidupan sehari-hari. Secara definitif, responden berupaya menjelaskan pengalamannya yang di dapat selama mempelajari seni rupa dan sebagai mahasiswa Seni Rupa Murni.

Pada hasil wawancara yang dilakukan oleh tim peneliti, ditemukan definisi secara konseptual yang dikemukakan oleh beberapa responden yang terhimpun, seperti halnya yang diargumentasikan oleh Imam Bukhori :
"Seni rupa itu saya rasa sebuah estesi yang dituangkan ke dalam sebuah media, bisa media apa saja, kalau seni rupa ya pasti dalam media yang bisa dinikmati oleh mata. Saya rasa media gak harus dengan pensil atau lukisan, dengan media-media lain seperti media cetak atau printing itu juga bisa, desain itu juga seni rupa, mencakup apa aja". (Wawancara dengan Imam Bukhori pada tanggal 1 Agustus 2018)

Menurut penuturan yang disampaikan oleh Imam Bukhori, seni rupa merupakan suatu estesi yang dapat di tuangkan ke dalam ragam media dengan segala bentuk media yang akan digunakan, lebih khususnya media visual yang dapat dinikmati secara kasat mata. Estesi yang ditekankan dalam kontestasi ini berupa suatu keindahan yang dapat dinikmati baik bagi perupa maupun penikmat yang memandangi karya seni tersebut.

Bentuk dan gaya seni rupa memiliki ragam yang cukup beraneka. Dalam kajian ini, dua gaya yang memiliki dua sisi kontradiktif namun memiliki kesinambungan dikaji secara kritis, yakni gaya seni rupa tradisional dan seni rupa kontemporer. Pada penelitian yang dilakukan, sejumlah responden dipilihkan berdasar pada pengalaman yang telah dimiliki setelah mengikuti mata kuliah seni rupa tradisional dan seni rupa kontemporer, sehingga se- 
jatinya telah mampu memberi analisis terkait perbedaan yang signifikan diantara kedua gaya dan bentuk populer dari seni rupa tradisional dan kontemporer.

Imam Bukhori, mahasiswa Seni Rupa Murni yang memberikan persepsinya terhadap perbandingan kedua bentuk dan gaya dari seni rupa tradisional dan kontemporer. Imam menjelaskan bahwa :

\begin{abstract}
"Seni rupa itu ada 2, seni rupa terapan dan seni rupa murni, kebetulan yang saya dalami ini adalah seni rupa murni, yang seni rupa murni ini tujuan pencip taannya adalah murni untuk keindahan, kita menciptakan kar ya seni ya hanya untuk keindahan kita saja. Ada juga seni rupa kontemporer, selain keindahan hal yang di pertimbangkan dari estesi seni rupa terapan itu adalah fungsionalnya, misal pro duk kriya seperti tas itu fungsio nalnya kan. Dia mempertimbang kan estetika tapi juga fungsio nalnya" (Wawancara dengan Imam Bukhori pada tanggal 1 Agustus 2018)
\end{abstract}

Secara definitif dapat dilihat bahwa perbedaan signifikan antara seni rupa murni (Tradisional) dengan seni rupa terapan (Kontemporer) adalah secara estetika dan fungsionalnya. Dalam seni rupa murni, estetika menjadi hal yang utama dan tujuan penciptaannya di tujukan murni hanya untuk keindahan saja. Berbeda halnya dengan yang ada dalam seni rupa terapan (kontem- porer), tidak hanya nilai estetika saja yang dipertimbangkan, melainkan juga sisi fungsionalnya yang tidak hanya indah, tetapi memiliki nilai kegunaan yang tinggi yang perlu dipertimbangkan atau sisi fungsional.

Imam melanjutkan bahwa secara signifikan perbedaan diantara kedua seni rupa terletak pada secara teknik dan konseptual. Secara teknik, seni rupa tradisional lebih mempertimbangkan pada teknik pen -ciptaannya dan estesinya, sedangkan seni rupa kontemporer terletak pada segala hal yang menciptakan keindahan tanpa terikat sesuatu yang terpenting telah memiliki pengalaman estetis di dalamnya. Secara konseptual, bahwa seni rupa murni (tradisional) hanya mengutamakan keindahan secara visual sedangkan seni rupa kontemporer tidak memiliki keterikatan dengan sesuatu hal dengan terpengaruh modernitas sehingga segala hal yang sedih ataupun kacau dapat menjadi indah.

Berbeda halnya dengan pemahaman terkait seni rupa yang dikemukakan oleh Khairul Imam yang menjelaskan bahwa seni rupa adalah bentuk ekspresi yang dapat bersifat emosi kemudian dituangkan me -lalui media berbentuk karya visual yang diwujudkan ke dalam berbagai bentuk, dapat berbentuk dua dimen- 
si, tiga dimensi, maupun empat dimensi yang meliputi seni instalansi bentuk dimensi bentuk, gerak, suara, maupun dimensi ruang.

"Menurut saya, seni rupa adalah bentuk ekspresi kita dalam menuangkan ide gagasan atau konsep ke dalam sebuah karya visual dalam wujud 2 dimensi, 3 dimensi, atau 4 dimensi" (Wawan cara dengan Khairul Imam pada tanggal 2 Agustus 2018)

Secara karakteristik, tentunya kedua gaya dan bentuk seni rupa ini memiliki masing-masih khas yang membedakannya menjadi dua aliran yang kontradiktif namun memiliki kesinambungan. Secara karakteristik, seni rupa murni atau tradisional dapat dilihat dari bentuknya yang lebih terikat pada aturan-aturan tradisi yang telah ada sebelumnya. Pen -dapat ini dikemukakan oleh Sherly Debora yang menyatakan bahwa:

"Lebih Bersifat tradisional, bersifat statis terus bersifat dinamis, bersifat kebhinekaan, bersifat kebhinekaan iitu maksudnya budaya yang sudah ada kayak budaya dari suku-suku itu bisa di terapkan tapi kan berbeda-beda budayanya. Masih menggunakan aturan aturan budaya sebelumnya" (Wawancara dengan Sherly Debora pada tanggal 2 Agustus 2018)

Dapat ditarik kesimpulan bahwa dalam perjalanannya, seni rupa tradisional melalui bentuk tradisi yang mengikat secara norma dan budaya dari beragam suku dan budaya. Selain itu, seni rupa tradisional dapat bersifat statis dan dinamis tergantung dari bagaimana pengalaman estetis dan persepsi bagi penikmatnya. Selain karakteristik seni rupa tradisional, karakteristik yang khas dari seni rupa kontemporer secara jelas diungkapkan oleh Ari Wibowo :

"Seni kontemporer secara perkembangannya lebih mengikuti zaman, kalau seni rupa kontemporer mengekspresikan diri sama cenderung ke bentukbentuk unik atau inovatif' (Wawancara dengan Ari Wibowo pada tanggal 2 Agustus 2018)

Seni rupa kontemporer secara historis, transformasi, dan pengembangan tentunya terpengaruh oleh perkembangan zaman, pergerakan teknologi dan globalisasi yang mempengaruhi cara pandang atau paradigma masyarakat yang kemudian mengekspresikannya ke dalam seni rupa kontemporer. Lebih jauh lagi, bentuk-bentuk yang dihasilkan dari seni rupa kontemporer menjadi lebih unik dan inovatif karena banyak menemui pengalaman baru sesuai dari perkembangan peradaban manusia.

\section{Membuat Produk Seni Rupa}

Minat yang muncul dari pengalaman dan pembelajaran yang sudah diterima tentunya mendorong responden atau lebih luas lagi, 
mahasiswa Seni Rupa secara umum untuk mencintai karya-karya seni rupa hingga menciptakan produkproduk berupa karya yang indah dan dapat diminati oleh banyak kalangan. Dalam hal ini, mahasiswa dapat memilih kesukaan mereka terhadap seni rupa baik secara konsep, fungsi dalam bentuk karya ataupun gagasan. Seperti yang dikemukakan oleh Dewi Wulansari :

"Kalau produk seni rupa aku lebih suka tas, makram juga bagus (gelang) yang di buat temen dari DKV atau ISI karena belum komersil, limited, karena seniman hanya buat beberapa aja, satu atau dua aja" (Wawancara dengan Dewi Wulansari pada tanggal 2 Agustus 2018).

Dewi Wulansari adalah mahasiswi Fakultas Seni Rupa dan Desain, Jurusan Seni Rupa Murni semester 2. Dewi menuturkan bahwa produk seni dapat menjadi salah satu karya yang tak hanya bernilai estetis tetapi juga memiliki nilai fungsional seperti halnya tas dan makram yang dibuat oleh seniman secara limited dan belum bersifat komersil. Berbeda halnya dengan yang disampaikan oleh Ari Wibowo yang berpendapat bahwa kesukaannya terhadap karya seni yang bernilai estetis dan memiliki pengalam an tentang emosi yang tertuang di dalam karya tersebut.
"Kalau mengamati, saya lebih suka mengamati karya seni lukis, soalnya mereka senimannya itu biasanya menyelipkan detai-detail khusus sama dari pengerjaannya pun pasti ada historinya sendiri" (Wawancara dengan Ari Wibowo pada tanggal 2 Agustus 2018)

Pendapat tersebut menjelaskan bahwa suatu karya seni rupa dapat memberikan sense tersendiri bagi penikmatnya tergantung pada latar belakang dan sudut pandang perupa atau seniman yang menuang -kan ekspresi ke dalam kanvasnya. Seni lukis yang umumnya berisi visualisasi dari simbol-simbol kehidupan, tentunya tidak terlepas dari sisi historis pelukis dengan emosionalnya mencipta karya seni rupa. Penggambaran ekspresi secara representative sejalan dengan yang dikemukakan dengan Khairul Imam yang beropini :

"Kalau saya cenderung suka seni kontemporer, karena itu saya lebih bebas di situ, biarpun aku mengambil tema-tema tradisi cuma kan tetep ada perkembangan-perkembangan tersendiri" (Wawancara dengan Khairul Imam pada tanggal 2 Agustus 2018).

Seni rupa kontemporer menceritakan tentang sisi-sisi ekspresi seperti halnya yang dirasakan Khairul Imam yang merasakan kebebasan dalam hasil karya setiap seniman kontemporer. Dengan rasa ketertarikan pada gaya dan bentuk seni 
rupa kontemporer tentunya mendorong Khairul menciptakan karya-karya dengan tema-tema khas dari dua gaya seni rupa, yakni tradisional dan kontemporer. Khairul meneruskan bahwa tema yang di ambil dalam menciptakan produk adalah tema tradisi dengan adaptasi dari perkembangan sisi kontemporer dalam karya seni rupanya. Sama halnya dengan karya yang dibuat oleh Ari Wibowo yang sudah menciptakan karya melalui kedua bentuk seni rupa, tradisonal dan kontemporer.

"Sejauh ini sudah, kalau yang tradisional itu mural di kawasan Pasar Kliwon membuat mural batik, melestarikan budaya lewat mural itu, sedangkan kalau kon temporer itu seperti yang ekspre sionis mengangkat isu-isu terkini lebih ke sosial bentuk karya lukis" (Wawancara dengan Ari Wibowo pada tanggal 2 Agustus 2018)

Selain mengutarakan bentuk eskpresi dan emosi dari perupa dalam membuat karya seni rupa, seni rupa juga dapat berperan sebagai media yang mampu melestarikan budaya lokal atau kearifan-kearifan lokal seperti dengan mencatutkan tema Batik ke dalam karya yang dibuat sebagai representasi dari simbol budaya Jawa. Selain melestarikan budaya, seni rupa juga dapat berperan dalam mengkaji isu-isu sosial dalam masyarakat yang dikemas dengan nilai estetis ke dalam karya Kriya seni lukis. Kecintaan pada aliran-aliran seni seperti surealisme contohnya, merupakan salah satu gagasan favorit bagi Imam Bukhori dalam menciptakan karyakaryanya.

"Sudah pernah, kebetulan tugas akhir saya juga lukisan surea lisme, saya menggunakan seni lukis tradisional cuma mungkin secara ide itu kontemporer, jadi bentuk visualnya apa yang ada di imajinasi saya. Tema yang sama ambil tentang disabilitas cuma itu sumber ide aja, secara makna lebih universal" (Wawancara de ngan Imam Bukhori pada tanggal 1 Agustus 2018)

Kolaboratif konseptual dan teknis pembuatan karya seni rupa dilakukan oleh Imam untuk dapat men -capai tujuan karya yang surealis dengan mengangkat tema disabilitas yang bermakna universal. Namun realitanya, setiap mahasiswa bahkan seniman sekalipun tentunya mengalami kesulitan dalam menciptakan karya-karya, terutama agar karyanya dapat diterima banyak kalangan. Salah satu kesulitan yang dihadapi oleh Sherly tentunya mungkin juga dirasakan oleh beberapa mahasiswa seni rupa lainnya.

"Kalau saya itu memang basicnya bukan seniman kaya gitu jadi kayak pemantapan kosnep itu gatau apa apa jadi kaya pusing duluan mikirnya lama, jadi pem buatan konsep harus dimatang kan dan itu yang lama" (wawan 
cara dengan Sherly Debora pada tanggal 2 Agustus 2018)

Kendala tersebut, tentunya tidak hanya dihadapi oleh Sherly Debora saja, karena banyak juga mahasiswa yang sejak awal tidak memiliki kemampuan atau basic sebagai seniman atau memiliki bakat yang kuat dengan seni terutama seni rupa murni. Kesulitan mencari gagasan dan gambaran yang dimiliki menilik pada pengalaman yang kurang karena bukan berasal dari kalangan seni sejak awal. Ada pula pendapat mahasiswa lain yang mengemukakan tentang kesulitannya dalam menciptakan karya-karya seni rupa yang baik secara estetika maupun secara fungsionalnya.

"Sebenarnya lebih ke teknis kalau ga terbiasa ga bisa, kalau konsep kan kita bisa membaca, tapi kalau aku sih teknis karena kurang latihan" (Wawancara dengan Khairul Imam pada tanggal 2 Agustus 2018)

Diperlukan latihan yang keras untuk memiliki keterbiasaan dalam membuat karya seni secara teknikal karena menurut Khairul, secara teknis akan lebih sulit daripada secara konsep. Teknik pembuatan akan mu -dah apabila terbiasa dan hal tersebut harus di bekali dari latihanlatihan yang disiplin, sedangkan kon- septual pembauatan karya dapat dicari melalui referensi yang dimiliki atau di luar wawasan dan pengalaman seniman.

\section{SIMPULAN}

Secara umum, pengalaman yang didapatkan oleh mahasiswa se -belum mengenal lebih jauh disiplin ilmu seni rupa dari bangku perkuliahan, mahasiswa sudah mendaseperti saat Sekolah Dasar maupun ekstrakulikuler, namun ada juga yang mendapatkan pengalamannya dari melihat-lihat pameran. Seni rupa memberikan daya tarik tersendiri dan memberikan kesan bagi pengalaman mahasiswa Seni secara umum karena seni rupa menjadi representasi penggambaran situasi dan perasaan bagi perupa yang menjadi medium penyampai pesan. Hal tersebut tertuang dalam bentuk karya yang dapat dinikmati dan diterima orang banyak, sehingga dapat dikatakan bahwa seni rupa dapat menjadi media komunikasi antara perupa dengan banyak orang yang dapat merasakannya dan menerima estetika yang ditawarkannya.

Bagi para mahasiswa seni rupa murni, seni rupa merupakan media visual yang dapat dinikmati secara kasat mata. Estesi yang ditekankan dalam kontestasi ini berupa 
suatu keindahan yang dapat dinikmati baik bagi perupa maupun penikmat yang memandangi karya seni tersebut.

Seni rupa tradisional dan kontemporer memiliki perbedaan yang signifikan. Seni Rupa tradisional melalui bentuk tradisi yang mengikat secara norma dan budaya dari beragam suku dan budaya. Selain itu, seni rupa tradisional dapat bersifat statis dan dinamis tergantung dari bagaimana pengalaman estetis dan persepsi bagi penikmatnya. Berbeda halnya dengan seni rupa kontemporer terletak pada segala hal yang menciptakan keindahan tanpa terikat sesuatu yang terpenting telah memiliki pengalaman estetis di dalamnya.

Karya seni rupa dapat memberikan sense tersendiri bagi penikmatnya tergantung pada latar belakang dan sudut pandang perupa atau seniman yang menuangkan ekspresi ke dalam kanvasnya. Karya seni rupa kontemporer berupa lukisan menjadi banyak diminati. Seni lukis yang umumnya berisi visualisasi dari simbol-simbol kehidupan, tentunya tidak terlepas dari sisi historis pelukis dengan emosionalnya mencipta karya seni rupa. Kebanyakan dari mahasiswa juga sudah mampu menciptakan karya baik berupa karya seni rupa yang terinspirasi dari pengalaman sebelumnya yang didapat sebelum dan setelah mendapatkan banyak ilmu di bangku perkuliahan.

Dalam membuat produk-produk, diperlukan latihan yang giat agar tidak menemui kendala. Secara umum, kesulitan yang ditemui saat membuat produk adalah secara teknis. Diperlukan latihan yang keras untuk memiliki keterbiasaan dalam membuat karya seni secara teknikal karena secara teknis akan lebih sulit daripada secara konsep. Teknik pembuatan akan mudah apabila terbiasa dan hal tersebut harus di bekali dari latihan-latihan yang disiplin, sedangkan konseptual pembuatan karya dapat dicari melalui referensi yang dimiliki atau di luar wawasan dan pengalaman seniman.

\section{DAFTAR PUSTAKA}

Anam, Choirul, Jajang Suryana, \& Langen Bronto Sutrisno, Pemetaan Kegiatan Seni Rupa Berdasarkan Laporan Hasil Skripsi Mahasiswa Pendidikan Seni Rupa FBS UNDIKSHA, Jurnal Jurusan Pendidikan Seni Rupa, Vol 4, No 1, pp: 1-9

Becker, H.S, 1982, Art World, Ca lifornia : University of Cali fornia Press, Berkeley 
Coates, Emily, 2017, The Poetics of Physics in Dance, PAJ: $A$ Journal of Performance and Art, Vol. 39, No. 2, pp. 7-21

Danial, E. \& Warsiah, 2009, Metode Penulisan Karya IImiah, Bandung: Laboratorium Pen didikan Kewarganegaraan, Depdiknas.

Elman, Erin \& Watts, Sheila, 2014, Primary Sources from the Fine and Performing Arts: Observe, Reflect, Explore, Teaching with Fine and Performing Arts, Vol. 7, No. 1, Fall 2014, pp. 2-8

Felix, John, 2012, Pengertian Seni Sebagai Pengantar Kuliah Sejarah Seni Rupa, HUMA NIORA, Vol.3 No.2 Oktober 2012, pp: 614-621

Galla, A. 2001. Guidebook for the Participation of Young Peo ple in Heritage Conser vation. Brisbane: Hall and jones Advertising.

Gustianingrum, Pratiwi Wulan dan Affandi, Idrus, 2016, Me maknai Nilai Kesenian Kuda Renggong dalam Upaya Me lestarikan Budaya Daerah di Kabupaten Sumedang, Journal of Urban Society's Art, Volume 3, No. 1, April 2016

Hardy, Tom, 2006, Art Education in a Postmodern World, Bristol UK: Intellect Ltd.

Hariyanto, Rudy. 2013. Pendapat Siswa Tentang Pembelajar an Apresiasi Seni Rupa Pada Pelajaran Seni Bu daya Siswa Kelas VII-C Di SMPN 13 Malang. Skripsi, Jurusan Seni dan Desain
Fakultas Sastra Universitas Negeri Malang.

Irianto, Agus Maladi, 2016, Komo difikasi Budaya di Era Eko nomi Global Terhadap Ke arifan Lokal: Studi Kasus Eksistensi Industri Pariwi sata dan Kesenian Tradisi onal di Jawa Tengah. Jurnal Theologia, Vol. 27, No. 1, pp. 212-236

Irianto, Agus Maladi, 2017, Kesenian Tradisional Sebagai Sarana Strategi Kebudayaan di Te ngah Determinasi Teknologi Komunikasi, NUSA, Vol. 12. No. 1 Februari 2017, pp: 90-100

Irianto, Agus Maladi, 2017, Kesenian Tradisional Sebagai Sarana Strategi Kebudayaan di Te ngah Determinasi Teknologi Komunikasi, NUSA, Vol. 12. No. 1 Februari 2017, pp. 90-100

Irianto, Asmudjo J. 2011. "1001 DOORS: Reinterpreting Tra ditions". Katalog Pameran 1001 Doors: Reinterpreting Tradition. Jakarta Contemporary.

Iswahyudi, 2010, Tinjauan Seni Ru pa Nusantara, Diktat, Yogya karta: Jurusan Pendidikan Seni Rupa FBS UNY, pp: 1 62

Kadir, Abdul, 1974, Diktat Estetika Timur (terjemahan dari Enci klopedia of the World Art), Yogyakarta : ASRI

Karja, I Wayan, 2007, Seni Rupa Kontemporer: Refleksi Nilai Lokal - Global, Jurnal War na,Vol.1 No.1 Juli 2007, pp: 33-49 
Nugroho, Budi Adi dan Himawan, Willy, 2014, Visual Tradisi dalam Karya Seni Lukis Kontemporer Sebagai Wu jud Artistik Pengaruh Sosial Budaya, Journal of Urban Society's Art, Volume 1 No. 2, Oktober 2014, pp. 99-109

Purwanto, 2006, Ruh Seni Tradisi Dalam Pendidikan Seni Ru pa Kita, Jurnal Imajinasi Vol 2, No 1 (2006)

Radzuan, I. S. M., Fukami, N., \& Ahmad, Y., 201,. Cultural Heritage, Incentives System and the Sustainable Com munity: Lessons from Ogi machi Village, Japan, Geo grafia: Malaysian Journal of Society and Space, Vol. 10, No. 1, pp. 130-146.

Ridwan, 2015, Problematika Keragaman Kebudayaan dan Alternatif Pemecahan (Pers pektif Sosiologi), Jurnal Ma daniyah, Volume 2 Edisi IX Agustus 2015, pp: 254-270

Sachari, Agus, Menafsir Pendidikan Multikultural dalam Mata $\mathrm{Pe}$ lajaran Seni Budaya (Seni Rupa) di Tingkat, Jurnal Pendidikan Seni "Kagunan", Desember 2006

Widiastuti, 2013, Analisis SWOT Keragaman Budaya Indo nesia, Jurnal IImiah WIDYA, Volume 1 Nomor 1 Mei-Juni 2013, pp: 8-14

Wiratmoko, Condro, 2017, Digitali sasi Pembelajaran Seni Budaya: Pembelajaran Mo tif Batik di SMA Negeri 2 Surabaya, Seminar Nasio nal Seni dan Desain: "Mem bangun Tradisi Inovasi Me lalui Riset Berbasis Praktik Seni dan Desain" FBS Unesa, 28 Oktober 2017

Yudoseputro, Wiyoso. "Seni Rupa Klasik", Pameran Kias 19 90-1991 "Perjalanan Seni Rupa Indonesia; dari Za man Prasejarah Hingga $\mathrm{Ma}$ sa Kini".Penerbit Panitia Pameran KIAS 1990-1991, Seni Budaya-Bandung

Yustiono, 1995, Seni Rupa Kontem porer Indonesia dan Era Asia-Pasifik, Wacana: Jur nal Seni Rupa, Vol. 2, pp. 57-62

Zulkifli, 2012, Strategi Pembelajaran Seni Budaya di Sekolah (Seni Rupa dalam Materi Seni Budaya), Seminar Se mirata Bidang Bahasa, Sastra, dan Seni Badan Ker jasama PTN Wilayah Barat, 26-27 Sep 2012, Bengkulu

Sutopo, H.B., 1996, Metodologi Penelitian Kualitatif, Sura karta: Universitas Sebelas Maret Press

Nasution, S., 2003, Metodologi Pene litian Naturalistik - Kualitatif, Bandung: CV Tarsito 